\title{
A Wetland Restoration Spatial Analysis in the Lower Reaches of Songhua River (LRSR), Northeast China
}

\author{
DONG Zhang-yu, LIU Dian-wei， WANG Zong- \\ ming, TANG Xu-guang, JIA Ming-ming \\ Northeast Institute of Geography and Agricultural Ecology, \\ Changchun 130012, China; Graduate University of Chinese \\ Academy of Science, Beijing 10049, China
}

\author{
WANG Yan \\ Geological Survey of Anhui Province, Hefei 230001, China
}

\begin{abstract}
Wetlands in the Lower Reaches of Songhua River (LRSR) is one of the most important wetland distribution area. However, owing to expanded agricultural activities since the 1950s, wetlands in this area has decreased in size and deteriorated in quality. Wetlands restoration is necessary to improve the present situation. Using remote sensing and geographic information systems technologies, a wetland restoration model was established, and landscape structure factor, buffer factor, wetness index, farmland productivity and geomorphology were integrated in the model. The landscape and buffer data were derived from land cover data, wetness index and geomorphology data were derived from digital elevation model (DEM) data, and farmland productivity were derived from MODIS products. Based on these data layers, we identified sizes for wetland restoration. After the wetland restoration of the higher and lower priority area, the whole wetland area of LRSR was $682993 \mathrm{ha}$, increased $45.77 \%$ of the existing area.
\end{abstract}

Key words-Remote Sensing; Wetland Restoration; Songhua River Basin; Landscape Pattern

\section{INTRODUCTION}

Wetlands are characterized as biodiversity, natural resources, capable of high food production and buffering of the hydrological cycle (Flanagan 2010). They can not only provide a service as a habitat for highly endangered wildlife (Wagner and others 2008), but also have an important influence on the global environment, throughout the world, wetlands are described as a "storage area of natural genes" and the "kidney of nature" (Zhou and othes 2009). The excessive development and using of wetlands have led to global loss and degradation, arousing serious ecological crises and social problems. Therefore, it was imminent to realize wetland restoration through natural and artificial approaches (Jenkons and others 2010). Wetland restoration means restoring or reconstructing wetlands which were degraded by means of ecological technology or ecological engineering, and recovering the structure, functions and physical, chemical and biologic characters before disturbed, then playing its basic roles (Royal and Gardner 2009). Wetland restoration is commonly presented as an important strategy for maintaining and enhancing the ecological captial of ecosystems with limited scientific effort on this subject in China (Cui and Yang 2009).

The badly degradation of wetland ecosystem has brought about a series of regional environmental issues such as the drier climate, the declination of groundwater level, soil degradation and exhausted fertility, the reduced resources of animals and plants, as well as polluted environment (Liu and others 2004; Mo and others 2009). In order to reverse this trend, wetlands restoration projects must be implemented ( $\mathrm{Li}$ and Zhang 2010). Therefore, on the basis of the theory about wetland restoration, it is important and significant to make a suitable decision for spatial analysis of wetland restoration by means of GIS and RS technology for explore the wetlands restoration sites for Songhua River Basin for improving the property of ecosystem of this area (Jenkons, Murray and Kramer 2010; Li and Zhang 2010).

The purpose of this study is to find suitable sites for wetlands restoration using RS and GIS technologies. In this paper, we selected Songhua River Basin as the experimental area, from landscape feature, rivers and roads buffer, wetness index, landform feature and farmland productivity factor to identify the priority sites for wetland restoration based on spatial analysis. Given that there is no spatial analysis methods accurately available for the wetland restoration study. Our research presents a suitable starting point for such studies.

\section{MATERIALS AND METHODS}

\section{A. Study Area}

Songhua River Basin is one of the biggest rivers in China and its watershed is located between $41^{\circ} 42^{\prime}-51^{\circ} 48^{\prime}$ north latitude and $119^{\circ} 52^{\prime}-132^{\circ} 31^{\prime}$ east longitude (Sun, Zhou and Ren 2011), in the northeaster China. (Fig. 1) The Songhua River, located at the junction of the temperate and coldtemperate zones. The region has a long, cold winter, a torridy, rainy summer; and a dry, windy spring.

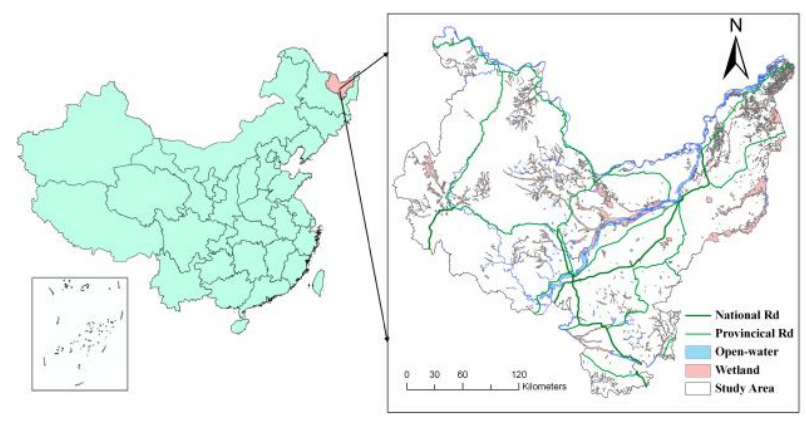

Fig. 1 Location of the Songhua River Basin in the Northeast China 


\section{B. Materials}

\section{1) Land cover}

Land-use data of the Songhua River Basin for 2005 was obtained by manual and Ecognition Developer 8.64 software interpretation of Landsat TM7 images. Extraction of land-use data according to the Chinese National Technical Standard for land-use Survey (Zhou, Wang, Khan and Zhao 2009; Huang, Wang and Liu 2010). The six land cover categories were: woodland, water-body, build-land, wetland, farmland, grassland and others. At last, the interpretation accuracy of the land-use for 2005 was about 90\%. With $91.3 \%$ and $99 \%$ interpretation accuracies of wetlands and residential, respectively.

\section{2) Buffer data}

The buffer factor includes river buffer, road buffer. The buffer data was obtained by Arcgis9.3 software using rivers and roads vector data, which were extracted from land-use data Fig.3 displayed the buffer data

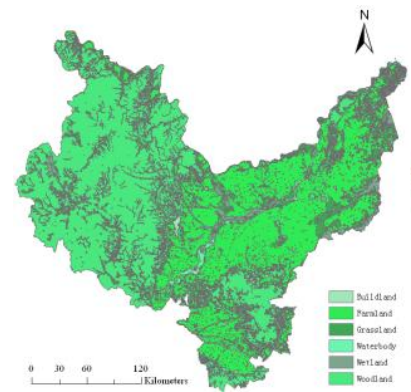

Fig. 2 Land use map
3) Landscape

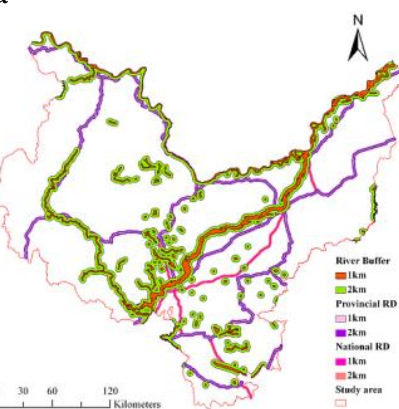

Fig. 3 River and Road buffer map
In this paper we used the Shannon diversity index (SHDI), Nearest neighbor coefficient of variation (NNCV), and interspersion and juxtaposition index (IJI) index. The landscape structure results were calculated by the software Fragstats3.3 (Griffth, Martiako and Price 2000; Megarigal and Marks 1995)

4) Wetness index

The wetness index controlling factor include surface topography, subsurface topography, hydro-geological characteristics of the aquifer. In this study, we only used the surface topography, which is the main controlling factor. We decide to compute the wetness index using a single-flow direction algorithm, which was implemented by Barling et al. (1994).

\section{5) Landform factor}

Landform types include plains, hills, mountains and valleys, plains, hills and valleys (Marco, Giancarlo and Federico 2002). In geography, these names are used for larger landscapes dominated by one landform type. In this study, only wash-land, lowland was considered. So we divided the landform types into wash-land, lowland, and others.

\section{6) Farmland Productivity Factor}

The farmland productivity was reflected by the index of Net Primary Productivity (NPP), which refers to the dry organic material that accumulated in unit time per unit area by the green plants. NPP was a very good farmland productivity index because it could reflected. Many models have been developed to estimate NPP, which was divided into there categories: Process-based models, statistics models, and parameter models (Guo, Wang and Liu 2009).

\section{Method}

We identified sites to be converted to wetlands by overlaying landscape feature, river, road buffer factor, wetness index, landform feature data, and farmland productivity data layers using Arcgis 9.3 software. Based on multi-criteria evaluation theory in a GIS framework to incorporate the above factor criteria, Considering that the purpose of converting to wetlands is to improve the fragile ecological environment in the Songhua River Basin, the model for identifying sites to be converted to wetlands is described in Fig. 4, and the hierachic grade of wetlands restoration is described in table 1 .

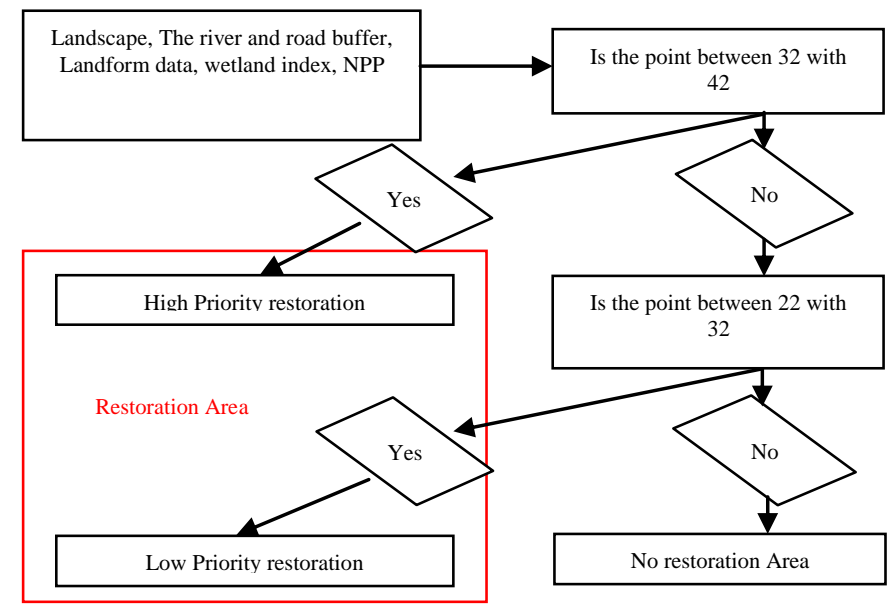

Fig. 4 The model for identifying sites for wetland restoration

\section{SITES FOR WETLAND RESTORATION}

Fig (5) displayed the spatial distribution of higher and lower priority wetlands restoration sites for the Songhua River Basin. The area and growth ratio of restored wetlands on Songhua River Basin was showed in table 2.

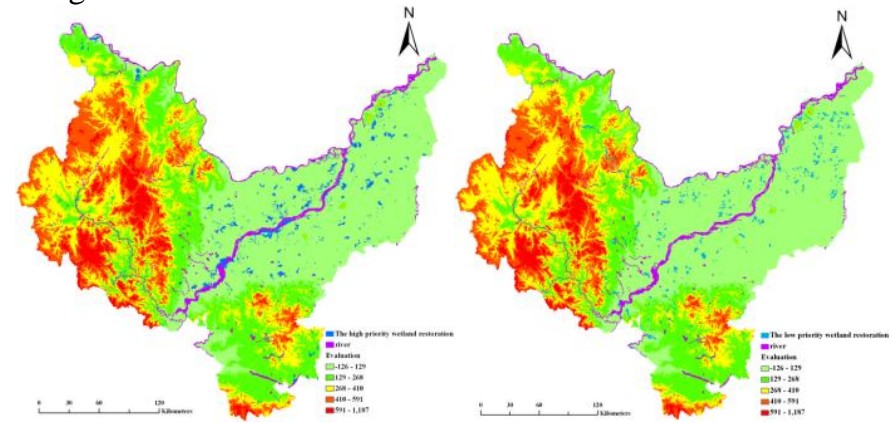

Fig. 5 High (Left) and low (Right) priority for wetland restoration

According to the model, which was described in Fig. 4, Table 2 shows the areas and growth ratio of restored wetlands in the Songhua River Basin, and Fig. 5, Fig. 6 displayed the spatial distribution of wetland restoration in the Songhua River Basin. We can found that the area of the higher priority restored wetlands was 161,046 ha, accounting for $2.08 \%$ of the total area of Songhua River Basin in 2005. Most of these sites were located on the coast of Songhua River, with some areas distributed in the northwest, and middle of the Songhua River Basin. While the area of lower priority restored wetlands was 
53,419 ha, accounting for $0.69 \%$ of the total area of Songhua River Basin in 2005 and the main distributed in the northeast, and middle of the study area, which were at the junction of the reaches of Songhua River and Heilongjiang River that took $27.69 \%$ of the lower restored wetlands. Judging from the whole space perspective, the restored wetlands were mainly concentrated on the middle regions of Songhua River Basin, and along the Songhua River, while there was little restoration on the southern area due to the mountainous topography, which was less possibility and significance to implement restoration.! After the restorations of the higher and lower priority restored wetlands, the total area of wetlands on Songhua River Basin was 682,993 ha, increasing $45.77 \%$ compared to 2005, which is close to the area of wetlands on Songhua River Basin in 1985.

\section{CONCLUSION AND DISSCUSION}

In this study, using RS and GIS technologies, we quantitatively identified and prioritized sites for wetlands restoration on Songhua River Basin. We proposed a comprehensive research program to thoroughly identify wetlands restoration sites for the Songhua River Basin.
The high priority and low priority restored wetlands on Songhua River Basin were designed by the wetland restoration model, which was described from five feature factor. The area of the wetlands on Songhua River Basin changed from 468,528 ha to 682,993 ha, increased $45.77 \%$. These provided reference data for the implement of wetland restoration on Songhua River Basin.

In a short term, wetland restoration may affect the crop productivity in some regions, but the data showed that the affect was not very serious; from the long-term point of view, the implementation of wetland restoration can effectively improve the regional ecological environment, regulate the local climate, control pollution and maintain the stability of ecosystem.

The wetland restoration model was developed from the spatial point, and the structured spatial decision model of wetland restoration was realized, the construction of general analysis software of spatial decisions on wetland restoration combining more comprehensive factors also need further exploration. Comprehensive evaluations of the effects of the wetland restoration from ecology, economic and society environment points were important domains to study.

TABLE I. The InDEX GRADE ASSIGNMENT TABLE

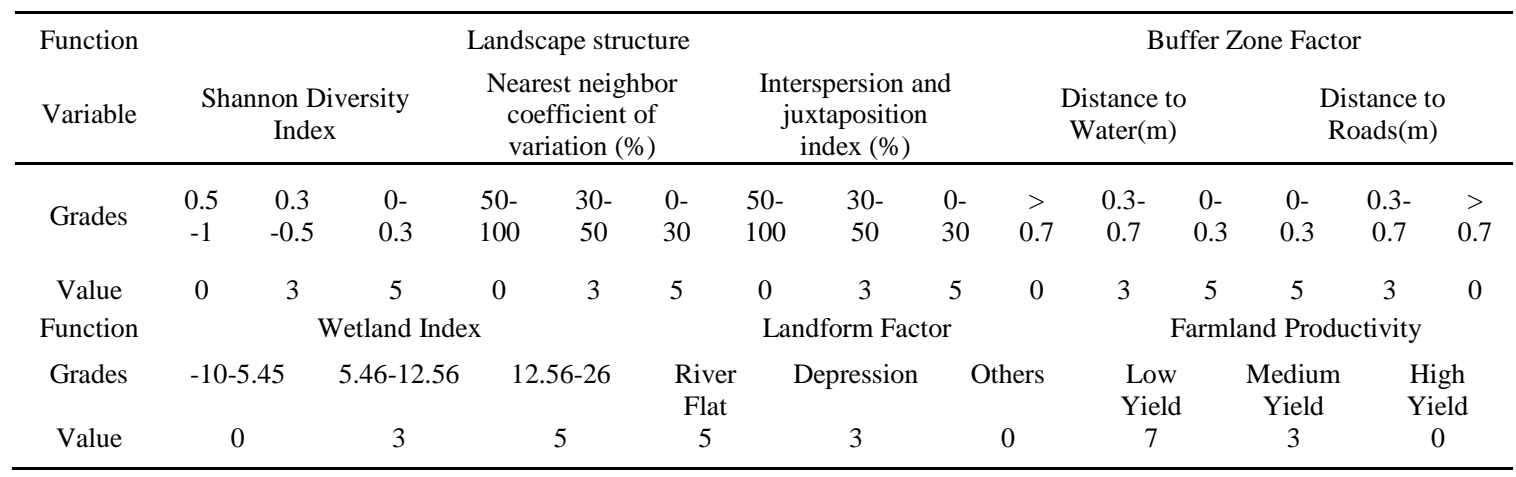

TABLE II. The Area And Growth Ratio of Restored Wetlands on Songhua River Basin

\begin{tabular}{ccccc}
\hline $\begin{array}{c}\text { Wetland restoration } \\
\text { class }\end{array}$ & Value field (score) & $\begin{array}{c}\text { Total } \\
\text { area (ha) }\end{array}$ & $\begin{array}{c}\text { Proportion } \\
\text { of the total study area } \\
(\%)\end{array}$ & $\begin{array}{c}\text { Increased ratio } \\
\text { of the present wetland } \\
\text { area }(\%)\end{array}$ \\
High priority & $32-42$ & 161046 & 2.08 & 34.37 \\
Low priority & $22-32$ & 53419 & 0.69 & 11.40 \\
others & $0-22$ & 7522417 & 97.23 & - \\
\hline
\end{tabular}

\section{REFERENCES}

[1] Flanagan NE, Richardson CJ (2010) A multi-scale approach to prioritize wetland restoration for watershed-level water quality improvement. Wetlands Ecol Manage 18:695-706

[2] Royal C. Gardner (2009) North American Wetland Mitigation and Restoration Policies Wetlands [J]. Ecological Management, 17:1-2.

[3] Wagner K I, Gallagher S K, Hayes M (2008) Wetland restoration in the New Millennium: Do research efforts match opportunities [J]. Restoration Ecology, 16(3):367-372.

[4] Cui BS, Yang QH, Yang ZF (2009) Evaluating the ecological performance of wetland restoration in the Yellow River Delta, China. Ecological Engineering 35:1090-1103.
[5] Liu YH, Zhang SK, Lu XG (2004) The Spatial-temporal Changes of Wetland Landscape Structure in Sanjiang Plain. Journal of Geographical Sciences, 59(3): 391-400. (in Chinese)

[6] Mo MH, Wang XL, Wu HJ (2009) Ecosystem Health Assessment of Honghu Lake Wetland of China Using Artificial Neural Network Approach. Chin. Geogra. Sci. 19(4):349-356.

[7] Li XW, Li C, Zhang LN (2010) Modeling the scenarios of wetland restoration in Hengshui Lake National Nature Reserve. Procedia Environmental Sciences, 2: 1279-1289.

[8] Huang N, Wang ZM, Liu DW, Niu Z (2010) Selecting Sites for Converting Farmlands to Wetlands in the Sanjiang Plain, Northeast China, Based on Remote Sensing and GIS. Environmental Management 46: 790-800 
[9] Sun XY, Zhou QX, Ren WJ (2011) Spatial and temporal distribution of acetochlor in sedimets and riparian soils of the Songhua River Basin in northeastern China. Journal of Environmental Sciences 23(10) 1684-1690

[10] Zhou DM, Gong HL, Wang YY, Shahbaz Khan, Zhao KY (2009) Driving Forces for the Marsh Wetland Degradation in the Honghe National Nature Reserve in Sanjiang Plain, Northeast China. Environ Model Assess 14:101-111

[11] Griffth JA, Martinko EA, Price K P (2000) Landscape structure analysis of Kansas at three scales. Landscape and Urban Planning 52: 45-61

[12] McGarigal K, Marks B (1995) FRAGSTATS: Spatial analysis program for quantifying landscape structure. Gen.TECH.Rep.PNW-GTR-35.USDA, Forest Service, Pacific, Northwest Research Station, Portland
[13] Barling DB, Morre ID, Grayson RB (1994) A quasi-dynamic wetness index for characterizing the spatial distribution of zones of surface saturation and soil water content. Water Resour. Res. 30(4), 1029-1044

[14] Marco B, Giancarlo D F, Federico C (2002) Analysis of topographic and climatic control on rainfall-triggered shallow land-sliding using a quasi-dynamic wetness index. Journal of Hydrology 268:56-71

[15] Guo ZX ,Wang ZM, Liu DW (2009) Productivity Analysis of Temporal and Spatial Characteristics of Farmland in Sanjiang plain. Journal of Agricultural Engineering, 25(1):249-253. (in Chinese)

[16] Zhou DM, Gong HL, Zhao LL (2008) Integrated ecological assessment of biophysical wetland habitat in water catchments: Linking hydro-ecological modeling with geo-information techniques. ecological modeling 214: 411-420. 